\title{
A Compact Review of Laser Welding Technologies for Amorphous Alloys
}

\author{
Jian Qiao ${ }^{1}$, Peng $\mathrm{Yu}^{1}$, Yanxiong $\mathrm{Wu}^{2}$, Taixi Chen ${ }^{3}$, Yixin $\mathrm{Du}^{1}$ and Jingwei Yang ${ }^{1, *}$ \\ 1 School of Mechatronic Engineering and Automation, Foshan University, Foshan 528000, China; \\ qiaoj@fosu.edu.cn (J.Q.); 2111851018@fosu.edu.cn (P.Y.); 2112052109@stu.fosu.edu.cn (Y.D.) \\ 2 School of Physics and Optoelectronic Engineering, Foshan University, Foshan 528000, China; \\ wuyanxiong@fosu.edu.cn \\ 3 Ji Hua Laboratory, Foshan 528000, China; chentx@jihualab.com \\ * Correspondence: mejwyang@fosu.edu.cn; Tel.: +86-15989111040
}

Received: 24 November 2020; Accepted: 17 December 2020; Published: 18 December 2020

\begin{abstract}
Amorphous alloys have emerged as important materials for precision machinery, energy conversion, information processing, and aerospace components. This is due to their unique structure and excellent properties, including superior strength, high elasticity, and excellent corrosion resistance, which have attracted the attention of many researchers. However, the size of the amorphous alloy components remains limited, which affects industrial applications. Significant developments in connection with this technology are urgently needed. Laser welding represents an efficient welding method that uses a laser beam with high energy-density for heating. Laser welding has gradually become a research hotspot as a joining method for amorphous alloys due to its fast heating and cooling rates. In this compact review, the current status of research into amorphous-alloy laser welding technology is discussed, the influence of technological parameters and other welding conditions on welding quality is analyzed, and an outlook on future research and development is provided. This paper can serve as a useful reference for both fundamental research and engineering applications in this field.
\end{abstract}

Keywords: laser welding; amorphous alloy; weld quality

\section{Introduction}

Amorphous alloys are an emerging class of advanced materials. Compared with conventional metals, their internal atoms are in a (long-range) disordered state. In addition, amorphous alloys have excellent mechanical, physical, and chemical properties, such as high elasticity, high permeability, and high strength and hardness [1]. Some of them have been selected as ideal materials for many industrial and civil applications, for example structural material, sporting goods, wear-/corrosion-resistant coatings, and transformers. In the 1960s, Klement et al. [2] first synthesized and investigated an Au-Si amorphous alloy at the California Institute of Technology. This research was further advanced by Chen et al. [3] during the 1970s. Subsequently, the group of Chen succeeded in producing a millimeter-level Pd-based bulk amorphous alloy [4]. In the late 1980s, research groups led by professors Inoue (Japan) and Johnson (USA) opened up new research directions for the field of amorphous alloys. Both groups produced important breakthroughs for the development and preparation of bulk amorphous alloys (amorphous alloys above millimeter-level size). This led to substantial improvements in the amorphous forming ability of this alloy system and the successful preparation of alloys like La-Al-TM [5-7], Mg-La-TM [8], Zr-Al-TM [9], Pd-Cu-Ni-P [10], and $\mathrm{Zr}-\mathrm{Al}-\mathrm{Cu}-\mathrm{TM}[11,12]$ (TM denotes a transition metal), as well as a series of bulk amorphous alloy systems. Since then, the field of amorphous alloys has experienced renewed interest, and a series of 
new amorphous alloy systems has been developed, which include $\mathrm{Zr}$ [13-15], $\mathrm{Pd}$ [16,17], Cu [18,19], Fe [20,21], Ti [22,23], Mg [24,25], Ni [26,27], and Zn-based [28] systems. As the preparation techniques and composition designs continue to advance, new possible amorphous alloy systems continue to be found, which also increases their range of industrial applications.

While amorphous alloys have excellent properties such as high elasticity, high permeability, and high strength and hardness that make them suitable for many industrial applications, there are also some disadvantages. For example, their preparation requires a very high cooling rate, and there are tight limits with respect to forming dimensions. In addition, high heating rates are required in order to keep the amorphous structure, especially for welding. Solving the problem of the size limitation is crucial to increase the range of applications. Many researchers have studied and developed new methods to overcome these limitations, such as additive manufacturing $[29,30]$, thermoplastic forming [31], and welding techniques. Laser welding, in particular, would be very suitable as it represents an efficient and precise welding method that uses a high energy-density laser beam for heating/melting. Other advantages of this technique are the fast welding speed, a stable welding process, high heating and cooling speeds, and a small heat-affected zone (HAZ). Compared to other welding methods, laser welding has important advantages for amorphous alloys.

This review aims to outline the latest research and existing problems for the laser welding of metallic glass. The important conclusions about laser welding of amorphous alloys are summarized at the end of this paper.

\section{Laser Welding of Amorphous Alloys}

\subsection{Introduction to Laser Welding}

Laser welding uses a high-energy laser beam to irradiate the surface of the materials. The temperature rises rapidly and evaporation leads to the formation of small holes. Heat transfers from the outer wall of the high-temperature cavity, which causes the metal surrounding the cavity to melt. As the laser beam moves, molten metal flows through the keyhole and rejoins at the original interface to form a weld, and the two materials connect. Figure 1 shows a schematic illustrating the principle of laser welding.

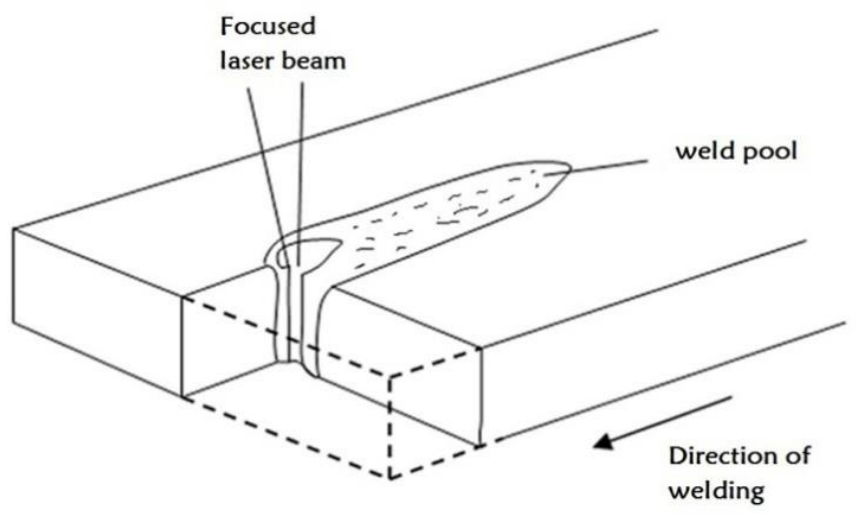

Figure 1. Schematic to illustrate laser welding.

\subsection{Effect of Process Parameters on the Weld Quality}

Thermodynamically, amorphous alloys are metastable and prone to changes in the microstructure by external factors. Once crystallization occurs during the melting and solidification of an amorphous alloy, the original excellent properties will be lost and lead to poor welding quality. Therefore, the evaluation of weld quality considers not only the geometry and performance of the weld but also whether the material maintains the amorphous structure. Kim et al. [32,33] used a Nd:YAG pulsed laser to weld 1-mm-thick $\mathrm{Cu}_{54} \mathrm{Ni}_{6} \mathrm{Zr}_{22} \mathrm{Ti}_{18}$ bulk amorphous alloy. The microstructure of the weld 
was investigated using scanning electron microscopy (SEM), micro-area X-ray diffractometry (XRD), and transmission electron microscopy (TEM). First, they analyzed the impact of the pulse energy on the welding quality and found that the larger the pulse energy, the easier it was to crystallize in the HAZ. Subsequently, the effect of frequency and speed on the welding quality was studied. Their results revealed that lower speeds and higher frequencies lead to crystallization within the HAZ. Finally, a weld without crystallization was obtained for a peak power of $1000 \mathrm{~W}$, a pulse width of $4 \mathrm{ms,}$ a frequency of $2 \mathrm{~Hz}$ and a speed of $60 \mathrm{~mm} / \mathrm{min}$. Louzguine-Luzgin et al. [34] used a fiber laser to weld a $\mathrm{Ni}_{53} \mathrm{Nb}_{20} \mathrm{Ti}_{10} \mathrm{Zr}_{8} \mathrm{Co}_{6} \mathrm{Cu}_{3}$ amorphous ribbon with a thickness of 25 micrometers. The two samples were successfully connected at a speed of $6 \mathrm{~m} / \mathrm{min}, 120 \mathrm{~W}$ power, and a wavelength of $\lambda=1.07 \mu \mathrm{m}$. As shown in Figure 2c, the high-resolution TEM image of the sample's weld area consists of a wider halo and a diffraction ring, which reveals a typical amorphous structure. However, some weak spot-like features within the amorphous halo suggest some medium-range order, which typically lies within the 0.5-1 nm length scale. In the SEM micrographs of certain areas of the polished part of the weld (Figure 2b), some particles were found to be embedded in the glassy matrix. These $\mathrm{ZrO}_{2}$ particles were confirmed using selected area electron diffraction (SAED) patterns-see Figure 2a. The amorphous structure of the welding sample did not change. However, to find out whether the $\mathrm{ZrO}_{2}$ particles affect the quality of the weld requires further study. This study also shows that it is necessary to provide good protection from oxidation during laser welding of amorphous alloys.
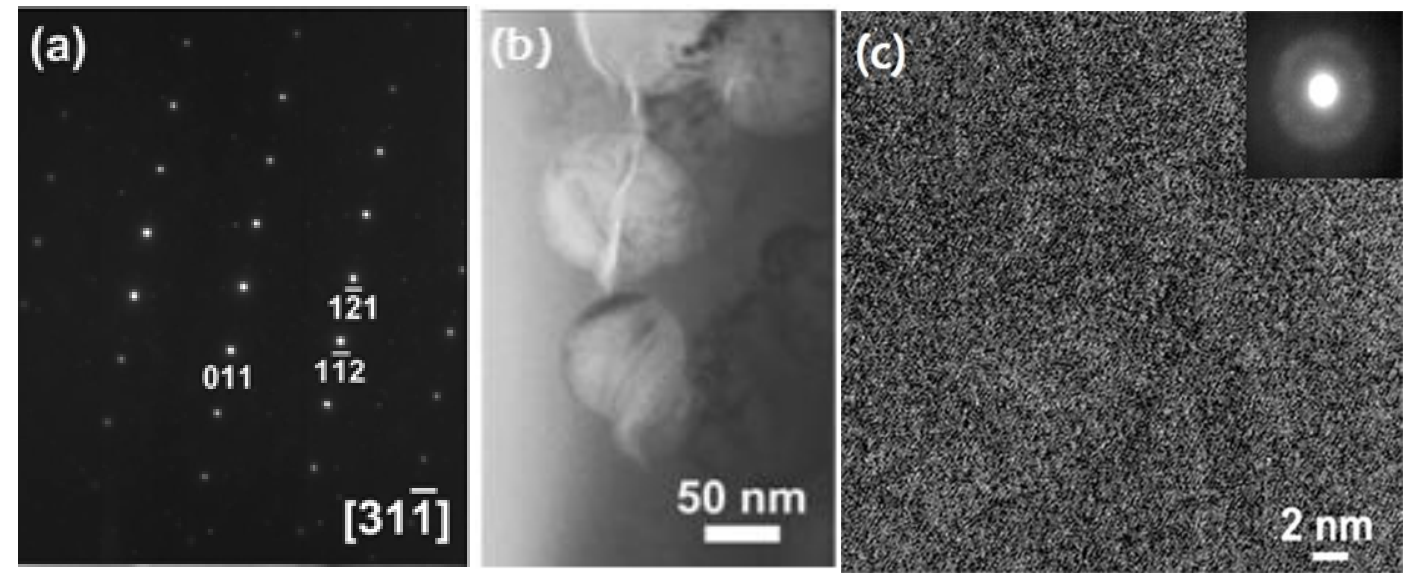

Figure 2. (a) Selected area electron diffraction (SAED) pattern for a particle in bright-field transmission electron microscopy (TEM) imaging mode. (b) Scanning electron microscopy (SEM) micrograph of the same sample. (c) High-resolution TEM image of the weld area [34] (with the permission of Elsevier).

Kawahito et al. [35] studied the feasibility of laser welding of Zr-based amorphous alloys. The group used a fiber laser with a laser power of $2.5 \mathrm{~kW}$ to weld a 1-mm-thick $Z_{55} \mathrm{Al}_{10} \mathrm{Ni}_{5} \mathrm{Cu}_{30}$ bulk amorphous alloy. The effect of different speeds on the crystallization of welds was studied. As a result, the fiber laser beam could be used to weld Zr-based metallic glass at an ultra-high speed at $72 \mathrm{~m} / \mathrm{min}$ and still maintain the amorphous state. Huei-Sen Wang et al. used a Nd:YAG laser to weld $\left(\mathrm{Zr}_{53} \mathrm{Cu}_{30} \mathrm{Ni}_{9} \mathrm{Al}_{8}\right) \mathrm{Si}_{0.5}$ [36] and $\left(\mathrm{Zr}_{44} \mathrm{Cu}_{36} \mathrm{Al}_{8} \mathrm{Ag}_{8} \mathrm{Ta}_{4}\right) \mathrm{Si}_{0.75}$ [37] bulk metallic glasses (BMGs). The microstructure evolution during laser-welding was studied by changing peak power, pulse width, and pulse energy. As shown in Figure 3, crystallization was observed in the HAZ at high pulse-energy but no crystallization occurred in the weld fusion zone (WFZ). Figure 4a shows a higher magnification of the crystalline phase in the HAZ, which further reveals the crystalline phase with a particle size of 30-200 nm in the precipitate (see Figure $4 \mathrm{~b}$ ). The particle size of the crystalline phase around the precipitated phase was about 20-30 nm (see Figure 4c). In addition, it can be observed (from the Figure 4a) that cracks formed in the central region of the precipitates, where the grain size of the crystalline phase exceeded 50 nanometers. The microstructure of the crystals in the HAZ is described in detail, which improves understanding of the crystallization properties of laser welding amorphous 
alloys. Pilarczyk et al. [38] studied the weld-surface morphology and nano-mechanical properties of Zr-based laser welded samples. As shown in Figure 5, a detailed analysis of the surface morphology indicates that the molten zone has a smooth surface, while the HAZ shows a slight roughness for the crystalline phase. Furthermore, a hardness test showed the nano-hardness of the HAZ below that of the smooth molten zone.
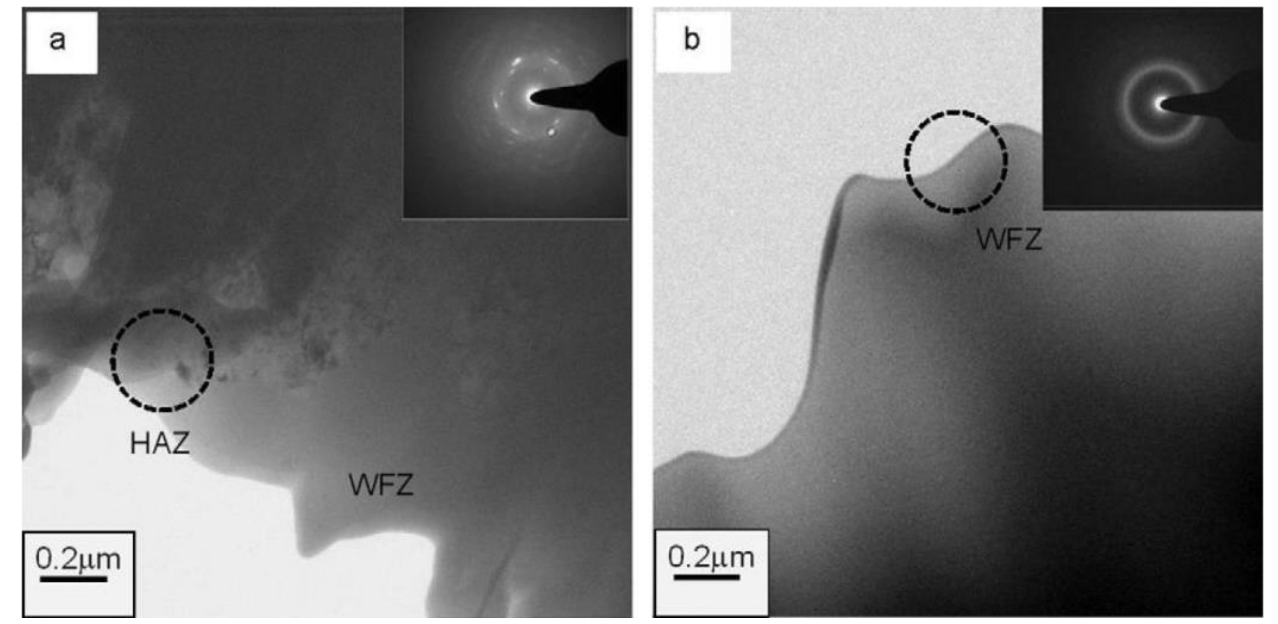

Figure 3. TEM bright-field images and selected area diffraction patterns for: (a) heat-affected zone (HAZ), (b) weld fusion zone (WFZ) [36] (with the permission of Elsevier).
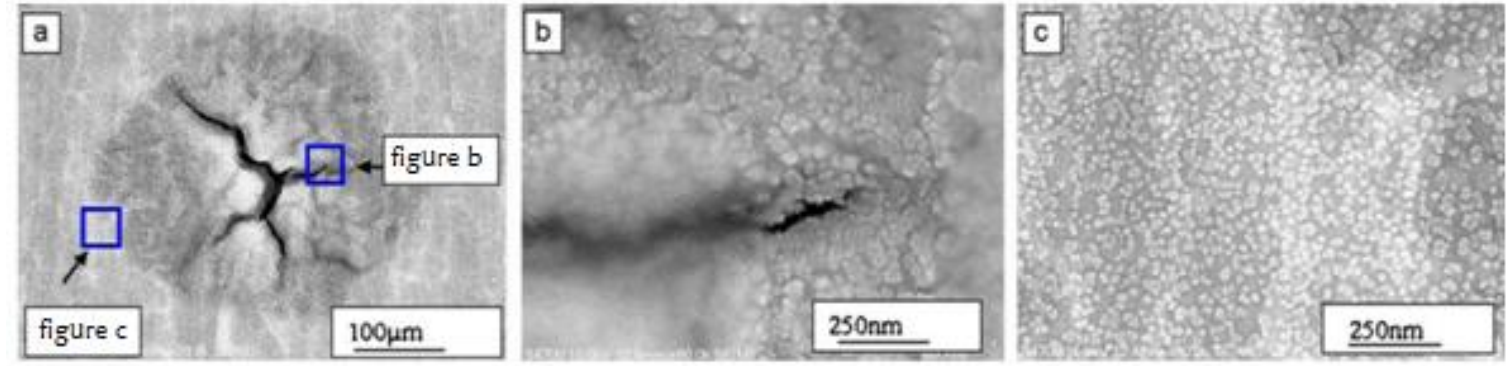

Figure 4. (a) Higher magnification of the crystalline phase within the HAZ, (b) crystalline phases in the central area of the precipitates with a particle size of 30-200 nm, (c) crystalline particles with a particle size of 20-30 nm [36] (with the permission of Elsevier).

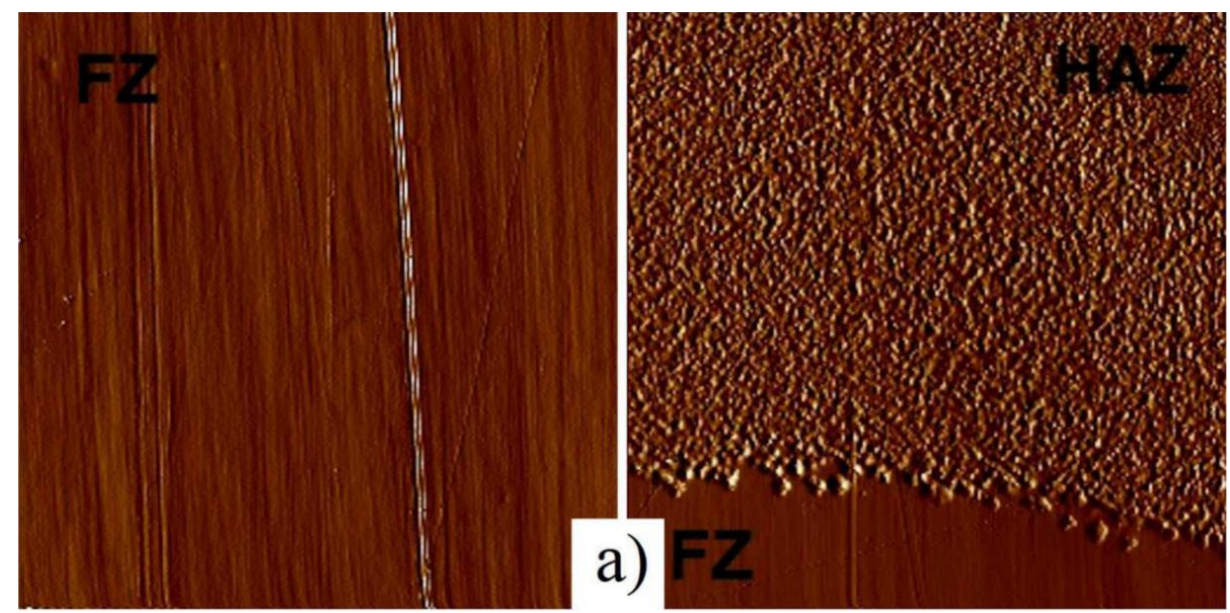

Figure 5. Cont. 


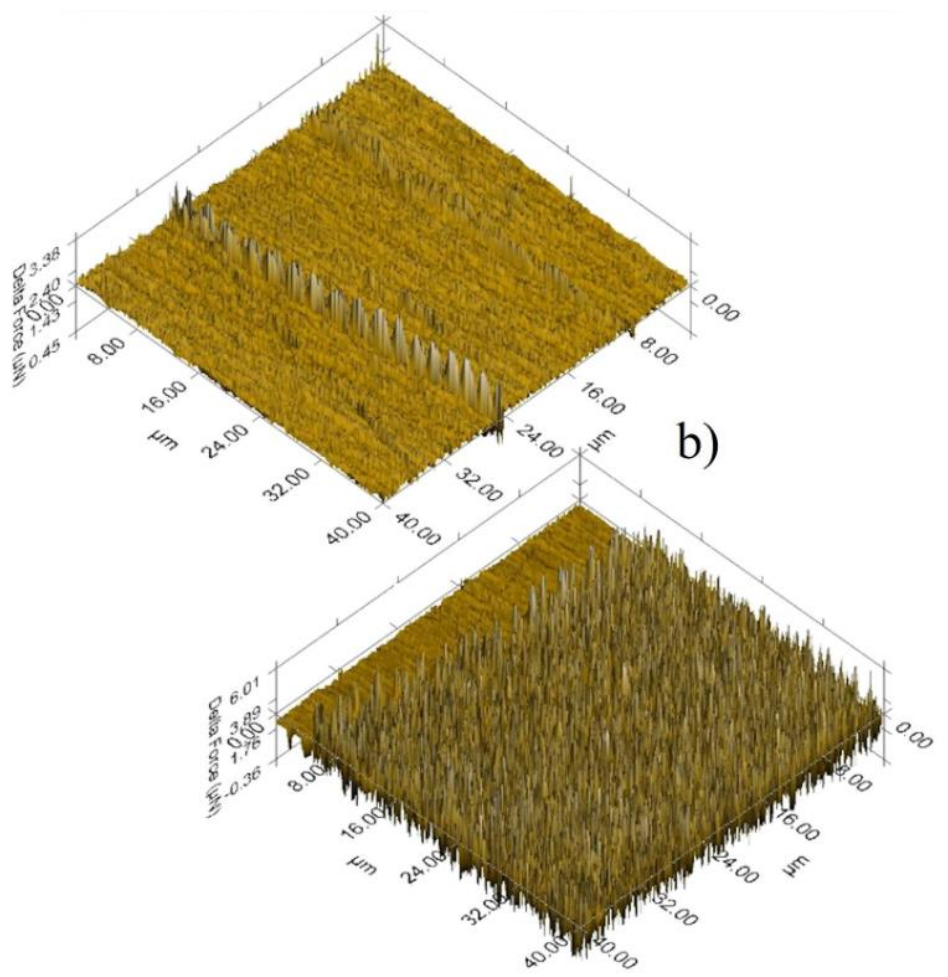

Figure 5. The surface morphology of a $\mathrm{Zr}-\mathrm{Cu}-\mathrm{Ni}-\mathrm{Al}$ laser weld in the fusion zone (FZ) and the HAZ: (a) 2D image, (b) 3D image [38] (with the permission of Polish Academy of Sciences).

G. Wang et al. [39] successfully welded an amorphous alloy $\mathrm{Ti}_{40} \mathrm{Zr}_{25} \mathrm{Ni}_{3} \mathrm{Cu}_{12} \mathrm{Be}_{20}$ block with a thickness of $3 \mathrm{~mm}$ using laser welding. The laser power was $3.5 \mathrm{~kW}$, the spot size was $0.2 \mathrm{~mm}$, and the welding speed was $6 \mathrm{~m} / \mathrm{min}$ to $10 \mathrm{~m} / \mathrm{min}$. It was concluded that, as the speed decreased, the degree of crystallization in the weld increased, and the tensile strength of the joint decreased. Minghua Chen et al. [40] used a pulsed Nd:YAG laser to weld $\beta$-Ti-dendrite-enhanced amorphous alloy. The effects of laser excitation current, pulse width, and welding speed on the microstructure of the joint were studied. The microstructures of the welding joints were observed and analyzed. The microstructure in the fusion zone (FZ) consisted of $\beta$-Ti grains and an amorphous matrix. As shown in Figure 6a, it was found that the size of the Ti particles in the melting zone was much smaller than in the base material. This caused the hardness of the melting zone to be slightly higher than that in the base material. This, again, is due to the rapid cooling rate and the impact of laser pulses on the molten zone. It was concluded that the increase of the laser-pulse excitation current introduced a strong shock-wave into the molten pool, which led to finer grains in the molten zone-see Figure 6b,c. The growth state of the grains in the weld was studied in detail, which can provide experimental evidence and guidance to improve laser-welding of amorphous alloys.

Some researchers have studied the laser welding process of Pd-base [41] and Fe-base [42,43] amorphous alloys. Similar to previous research, the amorphous properties of the HAZ and melting zone of the welded joint were determined using differential scanning calorimetry (DSC) and XRD. The microstructure and surface morphology of the weld joint was examined using X-ray analysis, atomic force microscopy, and high-resolution transmission electron microscopy. As shown in Figure 7, the X-ray diffraction pattern of the FZ showed wide fuzzy spectra, which are characteristic for amorphous structures. In addition, the surface morphology of the HAZ revealed a slightly rough characteristic, and the X-ray diffraction pattern showed small diffraction lines from the crystal phase, which indicate that the area was amorphous-crystalline. Furthermore, the nano-hardness of the melting zone was the same as that of the base material, while the nano-hardness of the HAZ was a little lower. This is consistent with previous research results of Zr-based amorphous alloys [38]. 


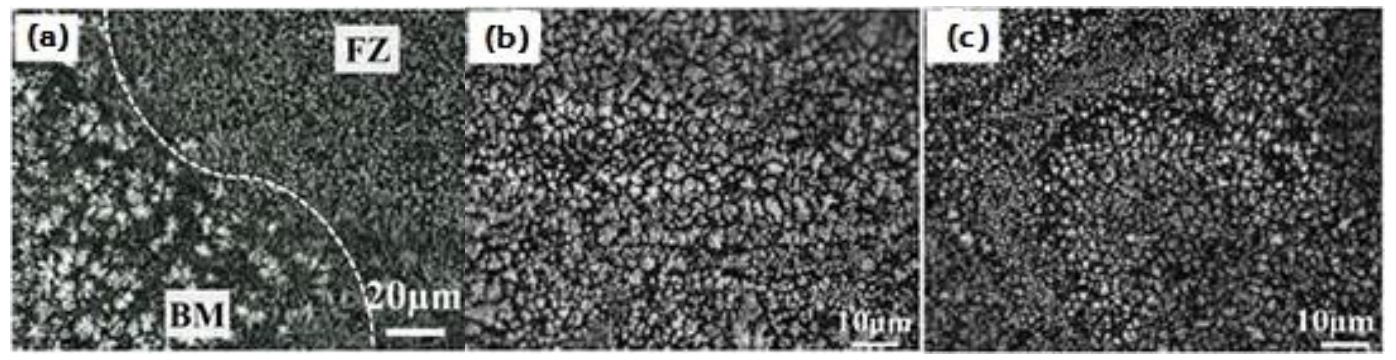

Figure 6. (a) Microstructure of the joints. Grains in the transition region in the weld joint: (b) laser-pulse electric current of $80 \mathrm{~A}$ and laser pulse energy of $6.0 \mathrm{~J}$; (c) laser-pulse electric current of $100 \mathrm{~A}$ and laser pulse energy of 8.6 J [40] (with the permission of Elsevier).
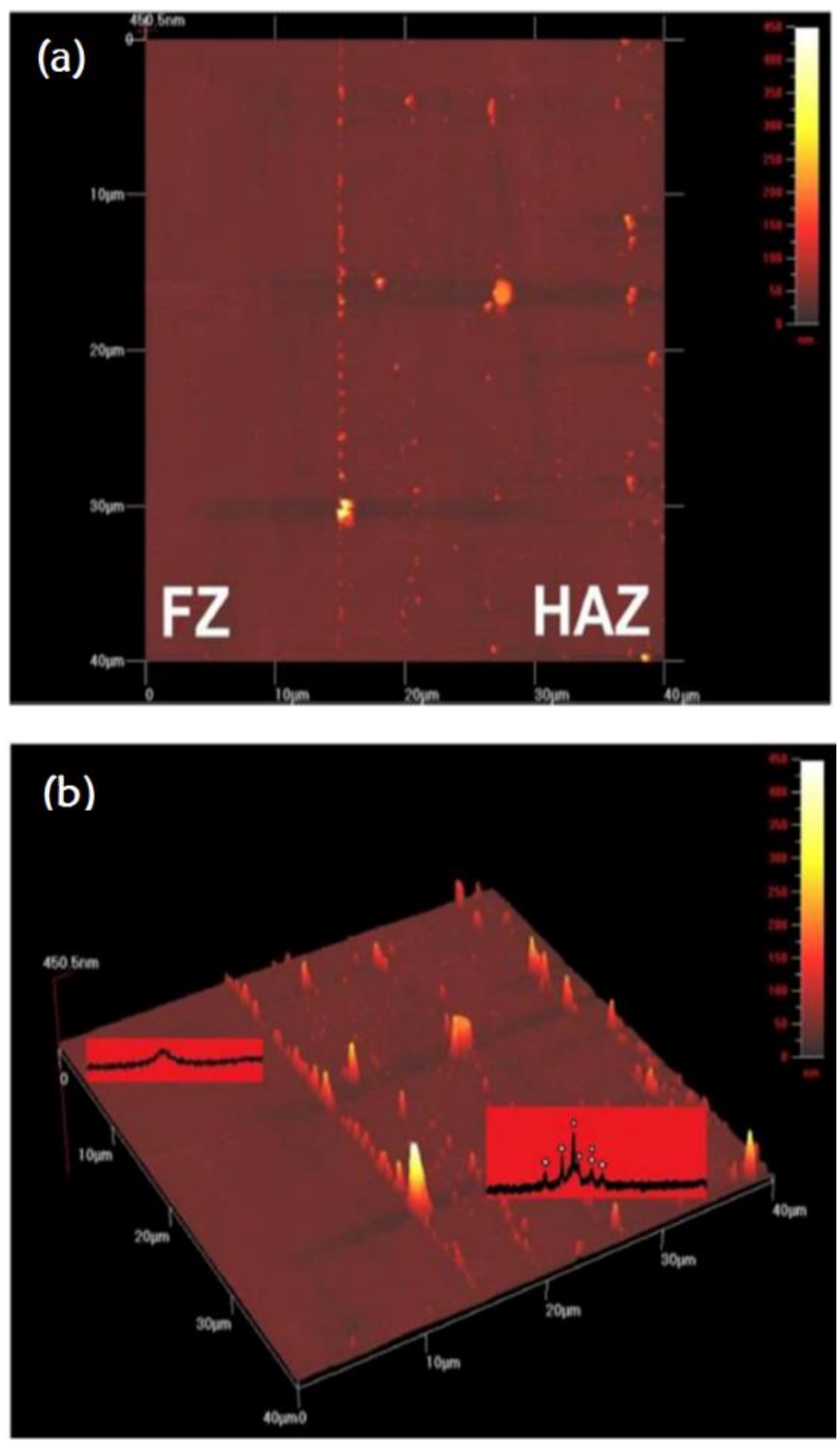

Figure 7. Surface morphology of the FZ and HAZ: (a) 2D image, (b) 3D image made by atomic force microscopy (AFM) with X-ray diffraction pattern [43] (with the permission of Polish Academy of Sciences). 
In recent years, researchers have used different laser systems to conduct welding process research for different metal-glass systems. It can be found from various studies that whether the amorphous alloy structure remains amorphous is the most important condition to measure the welding quality. Lower welding speed, higher pulse energy or laser power, and larger pulse width will lead to crystallization of amorphous alloy welding samples, thus affecting the welding quality.

\subsection{Effect of Other Welding Conditions on the Weld Quality}

Laser welding of amorphous alloys is a very complex process. There are several other welding parameters that affect the crystallization of the amorphous alloy in addition to the process parameters. For example, Huei-Sen Wang et al. $[44,45]$ studied the effect of the initial welding temperature on the weld quality, which was altered using a liquid cooling device. The microstructure evolution and mechanical properties of the welded samples were analyzed using a combination of SEM, TEM, DSC, and a Vickers microhardness test. It was found that, at low laser-energy and initial welding temperature (at $\left.0{ }^{\circ} \mathrm{C}\right)$, no crystallization occurred within the HAZ. In addition, the microhardness was similar to that of the base material. When the initial welding temperature was increased, a crystallized precipitate appeared in the heat-affected zone, and cracks were found in the crystallized precipitate in the crystallized zone. These cracks decreased the microhardness. When the initial welding temperature was $0^{\circ} \mathrm{C}$, no crystallization occurred in either the HAZ or the melting zone, and the properties of the welding sample did not change compared to the base material. Later research [46] confirmed this conclusion. When the initial welding temperature was $0{ }^{\circ} \mathrm{C}$, no crystallization occurred in the HAZ or the melting zone, and the properties of the welding sample did not change compared to the base material. This confirmed that decreasing the initial welding temperature can improve the weldability of amorphous alloy.

Chen Biao et al. [47] used a laser to weld annealed $\mathrm{Zr}_{55} \mathrm{Cu}_{30} \mathrm{Al}_{10} \mathrm{Ni}_{5}$ bulk amorphous alloy. The group studied the effect of the annealing process and welding parameters on the weld quality. As shown in Figure 8, the unannealed weld sample was completely crystallized, while the annealed weld sample retained some amorphous features. When the annealing temperature was $415^{\circ} \mathrm{C}$, and the annealing time was $10 \mathrm{~min}$, the SAED pattern of the weld sample showed a typical amorphous diffraction ring together with several bright specks-see Figure 8a. According to the above description, the sample maintained its amorphous structure and only a few nanocrystals were present in the sample substrate. Interestingly, due to the presence of nanocrystals, the welded joints of the sample had a higher microhardness and flexural strength than the unannealed samples. Therefore, it can be concluded that a suitable annealing temperature and time can improve the laser welding quality of Zr-based amorphous alloys.

According to a study by Pilarczyk [48], the metallurgical properties of amorphous alloys before welding have a great impact on the welding quality. Later, Huei-Sen Wang et al. [49] and Yiyu Shen et al. [50] conducted further research of this phenomenon. Because of the continuity of temperature during amorphous alloy casting, pre-existing nuclei cannot be avoided in any amorphous alloy casting process. Therefore, Yiyu Shen et al. investigated the effect of pre-existing nuclei on the crystallization of laser-welded Zr-based amorphous alloys. According to classical nucleation/growth theory, the evolution of a crystalline phase during laser welding of amorphous alloys was analyzed. The results show that the samples with higher pre-existing nuclear density were more likely to crystallize under the same laser welding conditions. The nuclear density of amorphous-alloy castings can be reduced by increasing the cooling rate during casting. Therefore, increasing the cooling rate improves laser welding of amorphous alloy casting parts.

It is useful to change other laser welding conditions to avoid crystallization in the welding process. Reducing the initial welding temperature will increase the cooling rate and reduce the amount of crystal precipitation in the heat-affected zone, which is beneficial to improve the welding quality. In addition, appropriate annealing temperature and annealing time are beneficial to improve the weld quality, micro-hardness, and bending strength of the welded area. 


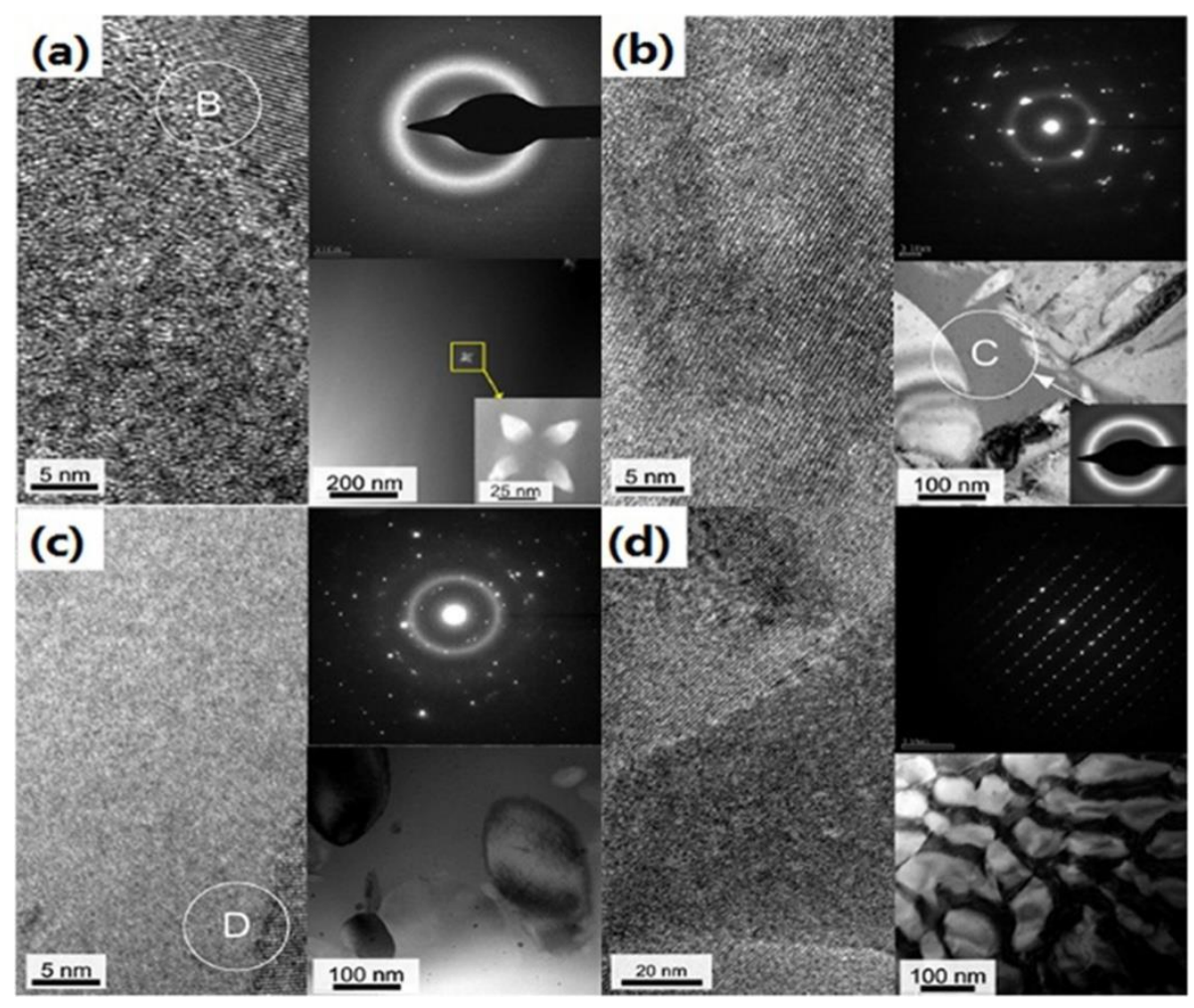

Figure 8. TEM images of the welding joints for different annealing conditions (a) annealing temperature: $415^{\circ} \mathrm{C}$, annealing time: $10 \mathrm{~min}(\mathbf{b})$ annealing temperature: $415^{\circ} \mathrm{C}$, annealing time: $30 \mathrm{~min}(\mathbf{c})$ annealing temperature: $430^{\circ} \mathrm{C}$, annealing time: $10 \mathrm{~min}$, (d) not annealed [47] (with the permission of Elsevier).

\subsection{Laser Welding of Amorphous Alloys and Crystalline Metals}

To expand the industrial application range of amorphous alloys, many researchers began to search for a welding method to combine amorphous alloys with conventional crystal metals. Chen Biao et al. [51] used an optical fiber laser to weld Zr-based bulk metallic glass and zirconium. The structure and quality of the welded joint were measured using SEM, TEM, and a hardness tester. Laser welding did not change the amorphous structure of BMG near the melting zone. At $1.3 \mathrm{~kW}$ and $8 \mathrm{~m} / \mathrm{min}$, no cracks or defects were observed at the welding joint, and the WFZ maintained the same hardness as the amorphous base material. The research revealed that laser welding can be applied to connect amorphous alloys with conventional metals. Alavi et al. [52] used the laser welding method to fill the gap of a 3-mm-thick plain carbon steel plate with Fe-based amorphous alloy powder. The 3-mm-thick steel substrate was successfully welded together, but the amorphous structure was not maintained in the laser bonding region. Pingjun Tao et al. [53] used a pulsed laser to weld $\mathrm{Zr}_{55} \mathrm{Cu}_{30} \mathrm{Ni}_{5} \mathrm{Al}_{10}$ plate-like BMG and alloy powder of the same composition. The surface layers of the BMG can be significantly intensified after the laser welding treatments. However, compared with the BMG matrix, the mechanical properties of HAZ are slightly lower.

Xiao Wang et al. [54] successfully welded Fe-based amorphous ribbon and copper foil via laser shock welding. The thickness of the Fe-based amorphous ribbon was $28 \mu \mathrm{m}$, and the thickness of the copper foil was $30 \mu \mathrm{m}$. A series of process experiments was conducted with different pulse energies. SEM micrographs of welding interfaces with different pulse energies are shown in Figure 9. The welding interface was straight for low pulse energy, while the welding interface was wavy at high pulse energy. The interface was subjected to greater impact and produced high plastic deformation and shear stress because of the high pulse energy. The amorphous structure of the Fe-based amorphous ribbon was not affected by laser welding when the pulse energy was $835 \mathrm{~mJ}$. In addition, the joints exhibited a higher degree of hardness than before the welding. These results show that the Fe-based 
amorphous ribbon and crystalline copper were successfully welded using laser impact welding and a good welding quality could be maintained.

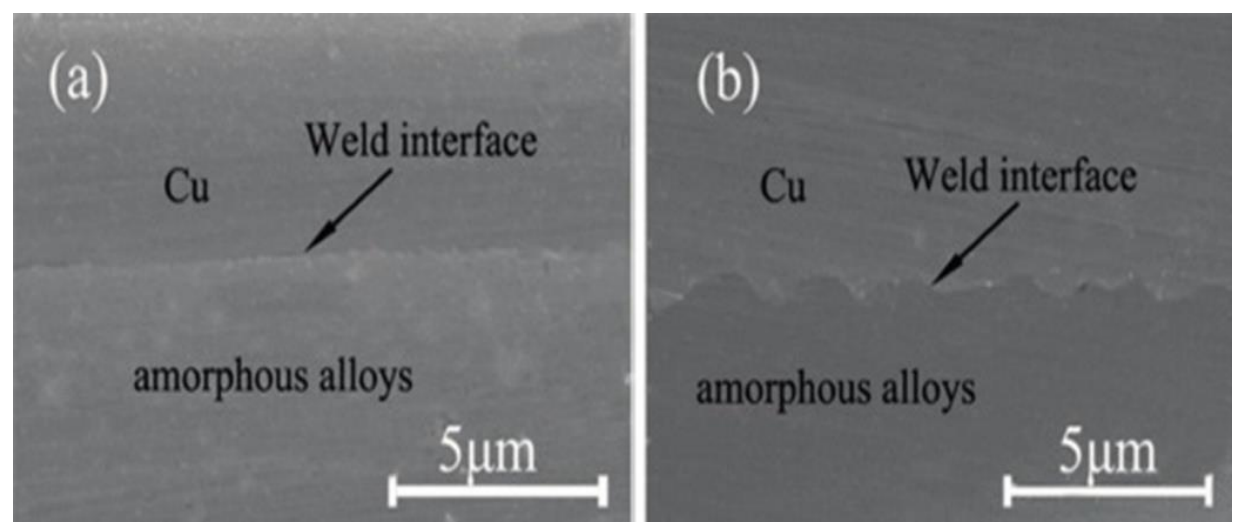

Figure 9. SEM micrographs of the welding interfaces obtained at different pulse energies: (a) $835 \mathrm{~mJ}$, (b) $1550 \mathrm{~mJ}[54]$.

Xiaoquan Yu et al. studied the laser-welding process of Zr-based bulk amorphous alloy with a 1100 aluminum alloy plate [55] as well as a copper plate [56]. The microstructure and chemical composition of the joint were analyzed using SEM and XRD, and the results are shown in Figure 10. The results show that the amorphous base-material maintained the amorphous structure, while $\mathrm{Zr}_{2} \mathrm{Ni}$ and $\mathrm{Zr}_{2} \mathrm{Al}$ phases appeared in the melting zone, the heat affected zone, and the junction between the melting zone and the aluminum alloy plate. The hardness test showed that the Vickers hardness of the joint exceeded that of the amorphous base-material, and the maximum hardness occurred at the junction of the aluminum plate with the welded joint. In the welding samples of Zr-based metallic glass and copper plate, both the molten zone and the amorphous base material zone maintained an amorphous characteristic. However, a crystalline phase of $\mathrm{Zr}$ and $\mathrm{Cu}$ appeared at the junction of the molten zone with the copper plate. The hardness of the amorphous structure in the molten zone was improved compared to the amorphous base material. The research results above confirm the feasibility of laser welding of amorphous alloys with crystalline metals. The hardness of the welded sample joint was improved compared to the parent material, which represents a new approach to extend the range of industrial applications for amorphous alloys.

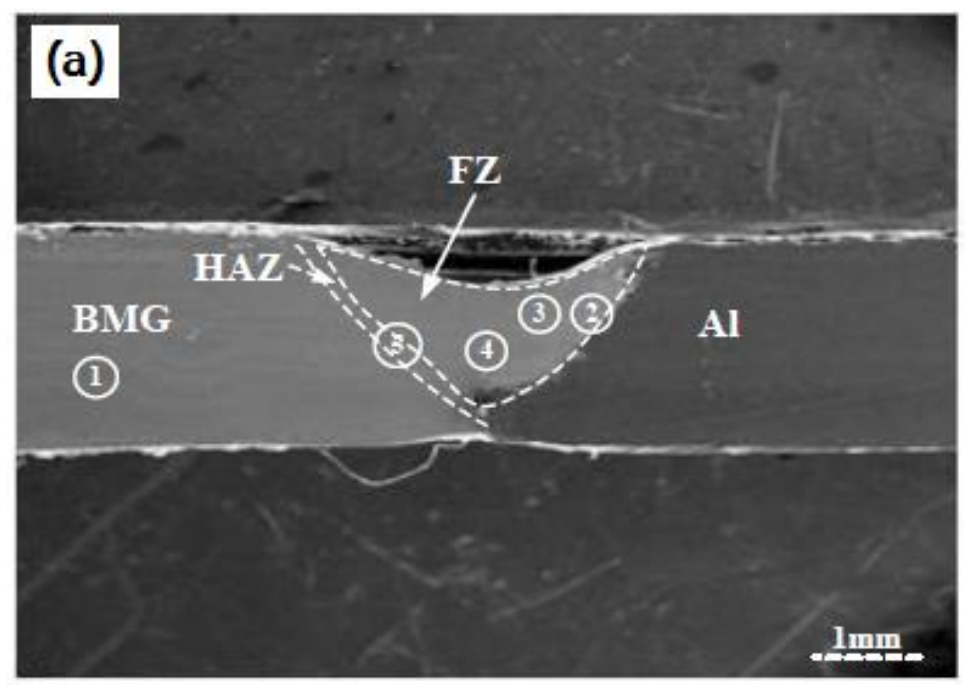

Figure 10. Cont. 


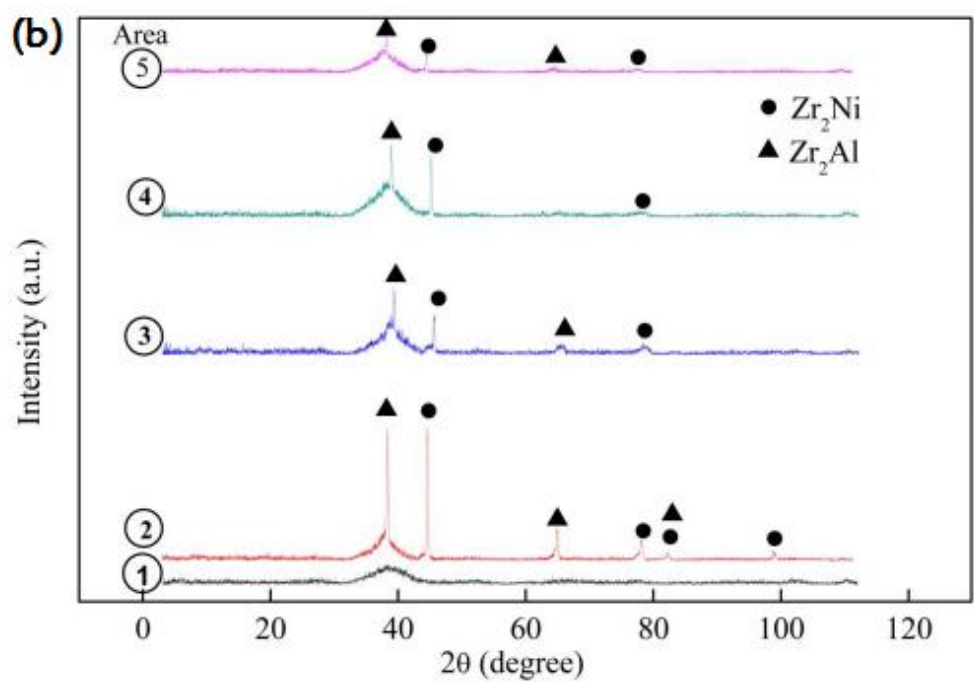

Figure 10. (a) SEM image of the joint, (b) micro-area X-ray diffractometry (XRD) patterns for the selected zones in the joint [55] (with the permission of IOP Publishing).

\section{Conclusions}

This review focused on the successful applications of laser welding technology for amorphous alloys. Laser welding, thanks to its high heating and cooling rates, is suitable for the welding of amorphous alloys. The technology is also very useful in solving the problem of size limitation for amorphous alloys in industrial applications, which expands the range of industrial applications significantly. Over the past decade, researchers have studied different laser systems to weld different amorphous alloys, the list is shown in Table A1 (Appendix A), and they have investigated the impact of process parameters and other welding conditions on the microstructure of amorphous alloys. They have also used several methods to characterize the quality of the welds. There have also been reports of laser welding between amorphous alloys and crystalline metals. Despite many reported studies, which provide valuable experimental support for the development and optimization of laser welding of metallic glass, much is still unknown.

The development of new laser-processing systems and amorphous alloy systems will continue to advance laser-welding technology, and many current obstacles could be overcome in the future. Because our understanding of the interaction between lasers and amorphous alloys is incomplete, it is necessary to study the involved mechanisms in more detail in the future. In addition, numerical simulations will be very useful, which can be used to assist in the design and optimization of laser welding of amorphous alloys. For example, by comparing the continuous heating transformation curve with the simulated temperature curve of the amorphous alloy, it is possible to predict when these interact, thus leading to crystallization during the welding process. To date, only a few studies have been done that used numerical simulations of laser welding of amorphous alloys. While this is a promising research direction, an accurate simulation is not a small challenge. Factors that need to be considered include vaporization, plasma effects, and any chemical composition changes in the materials. Finally, specific applications of laser-welded amorphous-alloy parts in industry should be investigated, which will promote the wider utilization of these materials in many industrial sectors.

Author Contributions: Conceptualization, J.Q. and Y.W.; writing-original draft preparation, P.Y. and Y.D.; writing-review and editing, J.Y. and T.C. All authors have read and agreed to the published version of the manuscript.

Funding: This research was funded by The National Natural Science Foundation of China (Grant No. 51805084), and the project funds support provided by Ji Hua Laboratory (Project No. X180081UZ180).

Conflicts of Interest: The authors declare no conflict of interest. 


\section{Appendix A}

Table A1. Materials and laser system used of the currently reviewed articles.

\begin{tabular}{|c|c|c|}
\hline Paper & Material & Laser System \\
\hline Kim et al. $[32,33]$ & $\mathrm{Cu}_{54} \mathrm{Ni}_{6} \mathrm{Zr}_{22} \mathrm{Ti}_{18}$ & Nd: YAG laser (pulsed) \\
\hline Louzguine-Luzgin et al. [34] & $\mathrm{Ni}_{53} \mathrm{Nb}_{20} \mathrm{Ti}_{10} \mathrm{Zr}_{8} \mathrm{Co}_{6} \mathrm{Cu}_{3}$ & fiber laser $(\mathrm{cw})$ \\
\hline Kawahito et al. [35] & $\mathrm{Zr}_{55} \mathrm{Al}_{10} \mathrm{Ni}_{5} \mathrm{Cu}_{30}$ & fiber laser $(\mathrm{cw})$ \\
\hline Huei-Sen Wang et al. $[36,37]$ & $\left(\mathrm{Zr}_{53} \mathrm{Cu}_{30} \mathrm{Ni}_{9} \mathrm{Al}_{8}\right) \mathrm{Si}_{0.5} /\left(\mathrm{Zr}_{44} \mathrm{Cu}_{36} \mathrm{Al}_{8} \mathrm{Ag}_{8} \mathrm{Ta}_{4}\right) \mathrm{Si}_{0.75}$ & Nd: YAG laser (pulsed) \\
\hline Pilarczyk et al. [38] & $\mathrm{Zr}_{55} \mathrm{Cu}_{30} \mathrm{Ni}_{5} \mathrm{Al}_{10}$ & TruLaser Station 5004 \\
\hline G. Wang et al. [39] & $\mathrm{Ti}_{40} \mathrm{Zr}_{25} \mathrm{Ni}_{3} \mathrm{Cu}_{12} \mathrm{Be}_{20}$ & Trumpf Trudisk 6002 \\
\hline Minghua Chen et al. [40] & TiZrBeCuMo & Nd: YAG laser (pulsed) \\
\hline Ling Shao et al. [41] & $\mathrm{Pd}_{43} \mathrm{Cu}_{27} \mathrm{Ni}_{10} \mathrm{P}_{20}$ & IPG Photonics 1500 \\
\hline Pilarczyk et al. [42,43] & $\mathrm{Fe}_{37.44} \mathrm{Co}_{34.56} \mathrm{~B}_{19.2} \mathrm{Si}_{4.8} \mathrm{Nb}_{4}$ & TruLaser Station 5004 \\
\hline Huei-Sen Wang et al. $[44,45]$ & $\left(\mathrm{Zr}_{53} \mathrm{Cu}_{30} \mathrm{Ni}_{9} \mathrm{Al}_{8}\right) \mathrm{Si}_{0.5}$ & Nd: YAG laser (pulsed) \\
\hline Huei-Sen Wang et al. [46] & $\left(\mathrm{Zr}_{53} \mathrm{Al}_{17} \mathrm{Co}_{29}\right)_{99} \mathrm{Ta}_{1}$ & Nd: YAG laser (pulsed) \\
\hline Chen Biao et al. [47] & $\mathrm{Zr}_{55} \mathrm{Cu}_{30} \mathrm{Al}_{10} \mathrm{Ni}_{5}$ & fiber laser $(\mathrm{cw})$ \\
\hline Pilarczyk [48] & $\mathrm{Fe}-\mathrm{Co}-\mathrm{B}-\mathrm{Si}-\mathrm{Nb}$ & TruLaser Station 5004 \\
\hline Huei-Sen Wang et al. [49] & $\left(\mathrm{Zr}_{48} \mathrm{Cu}_{36} \mathrm{Al}_{8} \mathrm{Ag}_{8}\right) \mathrm{Si}_{0.75}$ & Nd: YAG laser (pulsed) \\
\hline Yiyu Shen et al. [50] & $\mathrm{Zr}_{52.5} \mathrm{Ti}_{5} \mathrm{Al}_{10} \mathrm{Ni}_{14} \mathrm{Cu}_{17.9}$ & fiber laser $(\mathrm{cw})$ \\
\hline Chen Biao et al. [51] & $\mathrm{Zr}_{41} \mathrm{Ti}_{14} \mathrm{Cu}_{12} \mathrm{Ni}_{10} \mathrm{Be}_{23}$ and zirconium metal & fiber laser $(\mathrm{cw})$ \\
\hline Alavi et al. [52] & carbon steel and Fe-based amorphous alloy powder & fiber laser $(\mathrm{cw})$ \\
\hline Pingjun Tao et al. [53] & $\mathrm{Zr}_{55} \mathrm{Cu}_{30} \mathrm{Ni}_{5} \mathrm{Al}_{10}$ and alloy powder of the same composition & pulsed laser \\
\hline Xiao Wang et al. [54] & Fe-based amorphous alloys (GB1K101) and copper & Nd: YAG laser (pulsed) \\
\hline Xiaoquan Yu et al. [55] & $\mathrm{Zr}_{44} \mathrm{Ti}_{11} \mathrm{Ni}_{10} \mathrm{Cu}_{10} \mathrm{Be}_{25}$ and aluminum & Nd: YAG laser (pulsed) \\
\hline Xiaoquan Yu et al. [56] & $\mathrm{Zr}_{44} \mathrm{Ti}_{11} \mathrm{Ni}_{10} \mathrm{Cu}_{10} \mathrm{Be}_{25}$ and copper & Nd: YAG laser (pulsed) \\
\hline
\end{tabular}

\section{References}

1. Schroers, J. Processing of bulk metallic glass. Adv. Mater. 2010, 22, 1566-1597. [CrossRef] [PubMed]

2. Klement, W.; Willens, R.; Duwez, P. Non-crystalline structure in solidified gold-silicon alloys. Nature 1960, 187, 869-870. [CrossRef]

3. Chen, H.S.; Miller, C.E. A rapid quenching technique for the preparation of thin uniform films of amorphous solids. Rev. Sci. Instrum. 1970, 41, 1237-1238. [CrossRef]

4. Chen, H.S.; Krause, J.T.; Coleman, E. Elastic constants, hardness and their implications to flow properties of metallic glasses. J. Non-Cryst. Solids 1975, 18, 157-171. [CrossRef]

5. Inoue, A.; Kita, K.; Zhang, T.; Masumoto, T. An amorphous $\mathrm{La}_{55} \mathrm{Al}_{25} \mathrm{Ni}_{20}$ alloy prepared by water quenching. Mater. Trans. JIM 1989, 30, 722-725. [CrossRef]

6. Inoue, A.; Zhang, T.; Masumoto, T. Al-La-Ni amorphous alloys with a wide supercooled liquid region. Mater. Trans. JIM 1989, 30, 965-972. [CrossRef]

7. Inoue, A.; Nakamura, T.; Sugita, T.; Zhang, T.; Masumoto, T. Bulky La-Al-TM (TM = Transition Metal) amorphous alloys with high tensile strength produced by a high-pressure die casting method. Mater. Trans. JIM 1993, 34, 351-358. [CrossRef]

8. Inoue, A.; Kohinata, M.; Tsai, A.P.; Masumoto, T. Mg-Ni-La amorphous alloys with a wide supercooled liquid region. Mater. Trans. JIM 1989, 30, 378-381. [CrossRef]

9. Inoue, A.; Zhang, T.; Masumoto, T. Zr-Al-Ni amorphous alloys with high glass transition temperature and significant supercooled liquid region. Mater. Trans. JIM 1990, 31, 177-183. [CrossRef]

10. Inoue, A.; Nishiyama, N.; Matsuda, T. Preparation of bulk glassy $\mathrm{Pd}_{40} \mathrm{Ni}_{10} \mathrm{Cu}_{30} \mathrm{P}_{20}$ Alloy of $40 \mathrm{~mm}$ in diameter by water quenching. Mater. Trans. JIM 1996, 37, 181-184. [CrossRef]

11. Zhang, T.; Inoue, A. Density, thermal stability and mechanical properties of Zr-Ti-Al-Cu-Ni bulk amorphous alloys with high Al plus Ti concentrations. Mater. Trans. JIM 1998, 39, 857-862. [CrossRef]

12. Inoue, A.; Zhang, $\mathrm{T}$. Fabrication of bulk glassy $\mathrm{Zr}_{55} \mathrm{Al}_{10} \mathrm{Ni}_{5} \mathrm{Cu}_{30}$ alloy of $30 \mathrm{~mm}$ in diameter by a suction casting method. Mater. Trans. JIM 1996, 37, 185-187. [CrossRef]

13. Peker, A.; Johnson, W.L. A highly processable metallic glass: $\mathrm{Zr}_{41.2} \mathrm{Ti}_{13.8} \mathrm{Cu}_{12.5} \mathrm{Ni}_{10.0} \mathrm{Be}_{22.5}$. Appl. Phys. Lett. 1993, 63, 2342-2344. [CrossRef]

14. Lin, X.H.; Johnson, W.L. Formation of Ti-Zr-Cu-Ni bulk metallic glasses. J. Appl. Phys. 1995, 78, 6514-6519. [CrossRef] 
15. Hays, C.C.; Schroers, J.; Geyer, U.; Bossuyt, S.; Stein, N.; Johnson, W.L. Glass forming ability in the $\mathrm{Zr-Nb-Ni-Cu-Al} \mathrm{bulk} \mathrm{metallic} \mathrm{glasses.} \mathrm{J.} \mathrm{Metastable} \mathrm{Nanocryst.} \mathrm{Mater.} \mathrm{2000,} \mathrm{8,} \mathrm{103-108.} \mathrm{[CrossRef]}$

16. He, Y.; Schwarz, R.B.; Archuleta, J.I. Bulk glass formation in the Pd-Ni-P system. Appl. Phys. Lett. 1996, 69, 1861-1863. [CrossRef]

17. Nishiyama, N.; Inoue, A. Glass-forming ability of bulk $\mathrm{Pd}_{40} \mathrm{Ni}_{10} \mathrm{Cu}_{30} \mathrm{P}_{20}$ alloy. Mater. Trans. JIM 1996, 37, 1531-1539. [CrossRef]

18. Inoue, A.; Zhang, W.; Zhang, T.; Kurosaka, K. High-strength $\mathrm{Cu}$ based bulk glassy alloys in Cu-Zr-Ti and Cu-Hf-Ti ternary systems. Acta Mater. 2001, 49, 2645-2652. [CrossRef]

19. Dai, C.L.; Guo, H.; Shen, Y.; Li, Y.; Ma, E.; Xu, J. A new centimeter-diameter Cu-based bulk metallic glass. Scr. Mater. 2006, 54, 1403-1408. [CrossRef]

20. Ponnambalam, V.; Poon, S.J.; Shiflet, G.J. Fe-based bulk metallic glasses with diameter thickness larger than one centimeter. J. Mater. Res. 2004, 19, 1320-1323. [CrossRef]

21. Ponnambalam, V.; Poon, S.J.; Shiflet, G.J.; Keppens, V.M.; Taylor, R.; Petculescu, G. Synthesis of iron-based bulk metallic glasses as nonferromagnetic amorphous steel alloys. Appl. Phys. Lett. 2003, 83, 1131-1133. [CrossRef]

22. Inoue, A.; Nishiyama, N.; Amiya, K.; Zhang, T.; Masumoto, T. Ti-based amorphous alloys with a wide supercooled liquid region. Mater. Lett. 2007, 61, 2851-2854. [CrossRef]

23. Kim, Y.C.; Kim, W.T.; Kim, D.H. A development of Ti-based bulk metallic glass. Mater. Sci. Eng. A 2004, 375, 127-135. [CrossRef]

24. Ma, H.; Xu, J.; Ma, E. Mg-based bulk metallic glass composites with plasticity and high strength. Appl. Phys. Lett. 2003, 83, 2793-2795. [CrossRef]

25. Inoue, A.; Kato, A.; Zhang, T.; Kim, S.G.; Masumoto, T. Mg-Cu-Y Amorphous alloys with high mechanical strengths produced by a metallic mold casting method. Mater. Trans. JIM 1991, 32, 609-616. [CrossRef]

26. Choi-Yim, H.; Xu, D.H.; Johnson, W.L. Ni-based bulk metallic glass formation in the Ni-Nb-Sn and Ni-Nb-Sn-X (X= B,Fe,Cu) alloy systems. Appl. Phys. Lett. 2003, 82, 1030-1032. [CrossRef]

27. Yi, S.; Park, T.G.; Kim, D.H. Ni-based bulk amorphous alloys in the Ni-Ti-Zr-(Si, Sn) system. J. Mater. Res. 2000, 15, 2425-2430. [CrossRef]

28. Jiao, W.; Zhao, K.; Xi, X.K.; Zhao, D.Q.; Pan, M.X.; Wang, W.H. Zinc-based bulk metallic glasses. J. Non-Cryst. Solids 2010, 356, 1867-1870. [CrossRef]

29. Ge, Y.Q.; Chen, X.; Chang, Z.X. The forming and crystallization behaviors of $\mathrm{Zr}_{50} \mathrm{Ti}_{5} \mathrm{Cu}_{27} \mathrm{Ni}_{10} \mathrm{Al}_{8}$ bulk amorphous alloy by laser additive manufacturing. Mater. Express 2020, 10, 1155-1160. [CrossRef]

30. Luo, Y.; Xing, L.L.; Jiang, Y.D.; Li, R.W.; Lu, C.; Zeng, R.G.; Luo, J.R.; Zhang, P.C.; Liu, W. Additive Manufactured Large Zr-Based Bulk Metallic Glass Composites with Desired Deformation Ability and Corrosion Resistance. Meterials 2020, 13, 597. [CrossRef]

31. Li, N.; Chen, W.; Liu, L. Thermoplastic Micro-Forming of Bulk Metallic Glasses: A Review. JOM 2016, 68, 1246-1261. [CrossRef]

32. Kim, J.; Lee, D.; Shin, S.; Lee, C. Phase evolution in $\mathrm{Cu}_{54} \mathrm{Ni}_{6} \mathrm{Zr}_{22} \mathrm{Ti}_{18}$ bulk glass Nd: YAG laser weld. Mater. Sci. Eng. A 2006, 434, 194-201. [CrossRef]

33. Kim, J.H.; Lee, C.; Lee, D.M.; Sun, J.H.; Shin, S.Y.; Bae, J.C. Pulsed Nd: YAG laser welding of $\mathrm{Cu}_{54} \mathrm{Ni}_{6} \mathrm{Zr}_{22} \mathrm{Ti}_{18}$ bulk metallic glass. Mater. Sci. Eng. A 2007, 449, 872-875. [CrossRef]

34. Louzguine-Luzgin, D.V.; Xie, G.Q.; Tsumura, T.; Fukuda, H.; Nakata, K.; Kimura, H.M.; Inoue, A. Structural investigation of $\mathrm{Ni}-\mathrm{Nb}-\mathrm{Ti}-\mathrm{Zr}-\mathrm{Co}-\mathrm{Cu}$ glassy samples prepared by different welding techniques. Mater. Sci. Eng. B 2008, 148, 88-91. [CrossRef]

35. Kawahito, Y.; Terajima, T.; Kimura, H.; Kuroda, T.; Nakata, K.; Katayama, S.; Inoue, A. High-power fiber laser welding and its application to metallic glass $\mathrm{Zr}_{55} \mathrm{Al}_{10} \mathrm{Ni}_{5} \mathrm{Cu}_{30}$. Mater. Sci. Eng. B 2008, 148, 105-109. [CrossRef]

36. Wang, H.S.; Chen, H.G.; Jang, J.S.C. Microstructure evolution in Nd:YAG laser-welded $\left(\mathrm{Zr}_{53} \mathrm{Cu}_{30} \mathrm{Ni}_{9} \mathrm{Al}_{8}\right) \mathrm{Si}_{0.5}$ bulk metallic glass alloy. J. Alloys Compd. 2010, 495, 224-228. [CrossRef]

37. Wang, H.S.; Chiou, M.S.; Chen, H.G.; Jang, J.S.C.; Gu, J.W. Microstructure evolution of the laser spot welded Ni-free Zr-based bulk metallic glass composites. Intermetallics 2012, 29, 92-98. [CrossRef]

38. Pilarczyk, W.; Kania, A.; Babilas, R.; Pilarczyk, A. Structure and chosen nanomechanical properties of amorphous-crystalline laser weld. Acta Phys. Pol. A 2018, 133, 219-221. [CrossRef] 
39. Wang, G.; Huang, Y.J.; Shagiev, M.; Shen, J. Laser welding of $\mathrm{Ti}_{40} \mathrm{Zr}_{25} \mathrm{Ni}_{3} \mathrm{Cu}_{12} \mathrm{Be}_{20}$ bulk metallic glass. Mater. Sci. Eng. A 2012, 541, 33-37. [CrossRef]

40. Chen, M.H.; Lin, S.B.; Xin, L.J.; Zhou, Q.; Li, C.B.; Liu, L.; Wu, F.F. Microstructures of the pulsed laser welded TiZrBeCuMo composite amorphous alloy joint. Opt. Lasers Eng. 2020, 134, 106262. [CrossRef]

41. Shao, L.; Datye, A.; Huang, J.K.; Ketkaew, J.; Sohn, S.W.; Zhao, S.F.; Wu, S.J.; Zhang, Y.M.; Schwarz, U.D.; Schroers, J. Pulsed laser beam welding of $\mathrm{Pd}_{43} \mathrm{Cu}_{27} \mathrm{Ni}_{10} \mathrm{P}_{20}$ bulk metallic glass. Sci. Rep. 2017, 7, 7989. [CrossRef] [PubMed]

42. Pilarczyk, W.; Starczewska, O.; Lukowiec, D. Nanoindentation characteristic of Fe-based bulk metallic glass laser weld. Phys. Status Solidi B 2015, 252, 2598-2601. [CrossRef]

43. Pilarczyk, W.; Kania, A.; Pilarczyk, A. Welding and characterization of bulk metallic glasses welds. Acta Phys. Pol. A 2019, 135, 249-251. [CrossRef]

44. Wang, H.S.; Chen, H.G.; Jang, J.S.C.; Chiou, M.S. Combination of a Nd:YAG laser and a liquid cooling device to $\left(\mathrm{Zr}_{53} \mathrm{Cu}_{30} \mathrm{Ni}_{9} \mathrm{Al}_{8}\right) \mathrm{Si}_{0.5}$ bulk metallic glass welding. Mater. Sci. Eng. A 2010, 528, 338-341. [CrossRef]

45. Wang, H.S.; Chiou, M.S.; Chen, H.G.; Jang, J.S.C. The effects of initial welding temperature and welding parameters on the crystallization behaviors of laser spot welded Zr-based bulk metallic glass. Mater. Chem. Phys. 2011, 129, 547-552. [CrossRef]

46. Wang, H.S.; Li, T.H.; Chen, H.G.; Pan, J.H.; Jang, J.S.C. Microstructural evolution and properties of laser spot-welded $\mathrm{Zr}$-Al-Co-Ta bulk metallic glass under various initial welding temperatures. Intermetallics 2019, 108, 39-44. [CrossRef]

47. Chen, B.; Shi, T.L.; Li, M.; Yang, F.; Yan, F.; Liao, G.L. Laser welding of annealed $\mathrm{Zr}_{55} \mathrm{Cu}_{30} \mathrm{Ni}_{5} \mathrm{Al}_{10}$ bulk metallic glass. Intermetallics 2014, 46, 111-117. [CrossRef]

48. Pilarczyk, W. The investigation of the structure of bulk metallic glasses before and after laser welding. Cryst. Res. Technol. 2015, 50, 700-704. [CrossRef]

49. Wang, H.S.; Wu, J.Y.; Liu, Y.T. Effect of the volume fraction of the ex-situ reinforced Ta additions on the microstructure and properties of laser-welded Zr-based bulk metallic glass composites. Intermetallics 2016, 68, 87-94. [CrossRef]

50. Shen, Y.Y.; Li, Y.Q.; Tsai, H.L. Effect of pre-existing nuclei on crystallization during laser welding of Zr-based metallic glass. J. Non-Cryst. Solids 2019, 513, 55-63. [CrossRef]

51. Chen, B.; Shi, T.L.; Liao, G.L. Laser welding of $\mathrm{Zr}_{41} \mathrm{Ti}_{14} \mathrm{Cu}_{12} \mathrm{Ni}_{10} \mathrm{Be}_{23}$ bulk metallic glass and zirconium metal. J. Wuhan Univ. Technol. 2014, 29, 786-788. [CrossRef]

52. Alavi, S.H.; Vora, H.D.; Dahotre, N.B.; Harimkar, S.P. Laser joining of plain carbon steel using Fe-based amorphous alloy filler powder. J. Mater. Process. Technol. 2016, 238, 55-64. [CrossRef]

53. Tao, P.J.; Zhang, W.W.; Tu, Q.; Yang, Y.Z. The Evolution of Microstructures and the Properties of Bulk Metallic Glass with Consubstantial Composition LaserWelding. Metals 2016, 6, 233. [CrossRef]

54. Wang, X.; Luo, Y.P.; Huang, T.; Liu, H.X. Experimental Investigation on Laser Impact Welding of Fe-Based Amorphous Alloys to Crystalline Copper. Materials 2017, 10, 523. [CrossRef] [PubMed]

55. Yu, X.Q.; Huang, J.K.; Shao, L.; Zhang, Y.M.; Fan, D.; Wang, Z.Y.; Yang, F.Q. Microstructures and microhardness of the welding joint between $\mathrm{Zr}_{44} \mathrm{Ti}_{11} \mathrm{Ni}_{10} \mathrm{Cu}_{10} \mathrm{Be}_{25}$ bulk metallic glass and 1100 aluminum. Mater. Res. Express 2018, 5, 015203. [CrossRef]

56. Yu, X.Q.; Huang, J.K.; Shao, L.; Zhang, Y.M.; Fan, D.; Kang, Y.T.; Yang, F.Q. Microstructures in the joint of zirconium-based bulk metallic glass and copper. Mater. Res. Express 2019, 6, 026511. [CrossRef]

Publisher's Note: MDPI stays neutral with regard to jurisdictional claims in published maps and institutional affiliations.

(C) 2020 by the authors. Licensee MDPI, Basel, Switzerland. This article is an open access article distributed under the terms and conditions of the Creative Commons Attribution (CC BY) license (http://creativecommons.org/licenses/by/4.0/). 